
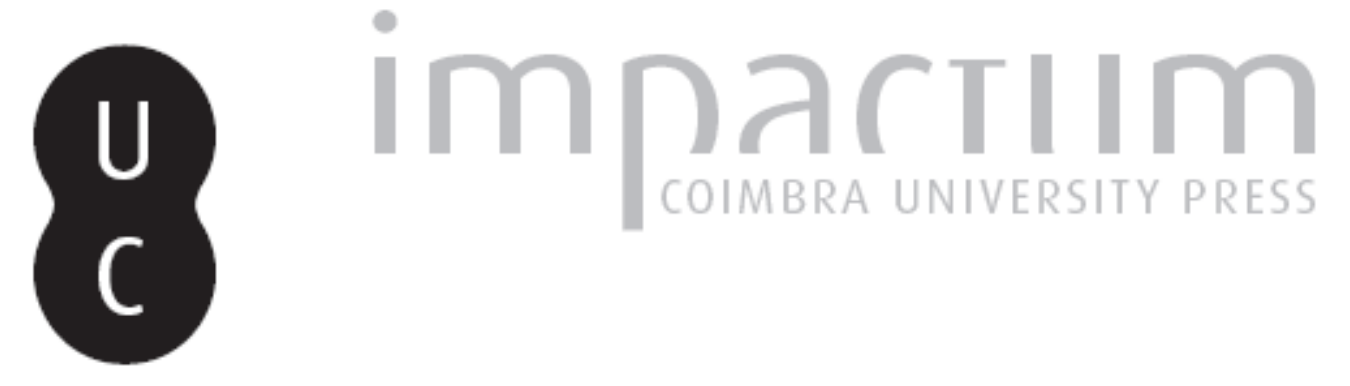

\title{
[Recensão a] LIRO Kajanto, The Latiu Cognomina
}

\author{
Autor(es): D'Encarnação, José
}

Publicado por: Imprensa da Universidade de Coimbra

URL persistente:

URI:http://hdl.handle.net/10316.2/45683

DOI:

DOI:https://dx.doi.org/10.14195/1647-8657_23_12

Accessed : $\quad$ 26-Apr-2023 12:01:08

A navegação consulta e descarregamento dos títulos inseridos nas Bibliotecas Digitais UC Digitalis, UC Pombalina e UC Impactum, pressupõem a aceitação plena e sem reservas dos Termos e Condições de Uso destas Bibliotecas Digitais, disponíveis em https://digitalis.uc.pt/pt-pt/termos.

Conforme exposto nos referidos Termos e Condições de Uso, o descarregamento de títulos de acesso restrito requer uma licença válida de autorização devendo o utilizador aceder ao(s) documento(s) a partir de um endereço de IP da instituição detentora da supramencionada licença.

Ao utilizador é apenas permitido o descarregamento para uso pessoal, pelo que o emprego do(s) título(s) descarregado(s) para outro fim, designadamente comercial, carece de autorização do respetivo autor ou editor da obra.

Na medida em que todas as obras da UC Digitalis se encontram protegidas pelo Código do Direito de Autor e Direitos Conexos e demais legislação aplicável, toda a cópia, parcial ou total, deste documento, nos casos em que é legalmente admitida, deverá conter ou fazer-se acompanhar por este aviso.

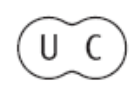


FACULDADE DE LETRAS

INSTITUTO DE ARQUEOLOGIA

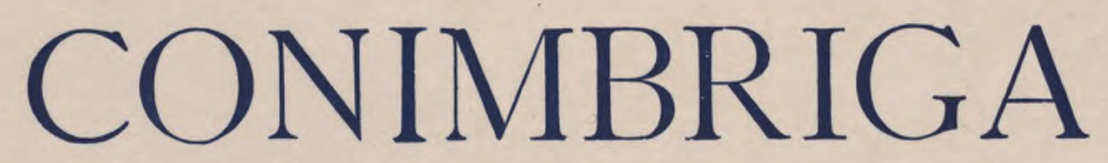

VOLUMEXXIII

UNIVERSIDADE DE COIMBRA

1984 


\section{RECENSÕES BIBLIOGRÁFICAS}

11 Ro Kajanto, The Latiu Cognomina, Helsínquia, 1965, 418 pág. Reimpressão: Giorgio Bretschneider Editore, Roma, 1982.

Apesar do constante aumento do número de inscrições romanas conhecidas, atestando bastas vezes novos antropónimos — o certo é que esta reimpressão do livro clássico de I. Kajanto sobre os cognomes latinos, em boa hora levada a efeito pela dinâmica iniciativa de G. Bretschneider, se apresenta não só (ainda) útil como fundamental.

$\mathrm{Na}$ verdade, se de 1965 para cá novidades não faltaram a complementar os dados antroponímicos fornecidos pelo GIL e seus suplementes (em que Kajanto se baseou), também se pode afirmar que eles serviram (quase) sempre para confirmar as tendências gerais apontadas por aquele investigador sueco, às quais, por conseguinte, ainda hoje nos podemos ater com segurança.

Por outro lado, a obra era demasiadamente rara, sendo pouquíssimas as boas bibliotecas que a possuíam, servindo-se os epigrafistas de exemplares fotocopiados a muito favor.

E não seria preferível uma 2 $^{\text {a }}$ edição, actualizada? Talvez não neste momento, em que um pouco por toda a parte se procede a uma revisão sistemática do CIL, tarefa a completar dentro de 5 a 6 anos. E a utilização da informática na elaboração dos índices permitirá, nessa altura, rigorosa actualização do The Latin Cognomina. Não sabemos se terá sido esta a intenção do editor e do autor, mas a opção é manifestamente boa, o livro da maior utilidade.

JOSÉ D'ENCARNAÇ̃̃O

José GuIllen, URBS ROMA - Vida y costumbres de los Romanos. III - Religión y ejército, Ediciones Sígueme, Salamanca, 1980. 628 pág., 8 estampas.

Terceiro volume duma obra que pretende traçar sintética panorámica do que foram a vida e os costumes dos Romanos, este trabalho do Prof. José

Conimbriga, 23 (1984), 207-227 